\begin{tabular}{c} 
Vol. 7 No. 1 Tahun 2021 \\
Jurnal Teknologi dan Manajemen Informatika \\
$\begin{array}{c}\text { http:// http://jurnal.unmer.ac.id/index.php/jtmi } \\
\text { P-ISSN: } 1693-6604\end{array}$ \\
\hline
\end{tabular}

\title{
Analisis Persepsi Produk Kosmetik Menggunakan Metode Sentiment Analysis Dan Topic Modeling (Studi Kasus: Laneige Water Sleeping Mask)
}

\author{
Ken Dheanis Adhine Salsabila ${ }^{1}$, Nurvita Trianasari ${ }^{2}$ \\ ${ }^{1,2}$ Telkom University, Indonesia
}

Info Artikel

Riwayat Artikel

Diterima: 18-03-2021

Direvisi: 20-05-2021

Disetujui: 04-06-2021

$\underline{\text { Kata Kunci }}$

Persepsi Konsumen;

Data Mining;

Sentiment Analysis;

Topic Modeling;

Corresponding Author

Ken Dheanis Adhine

Salsabila,

Telkom University,

Tel. +6282215286952

adhinesalsabila@gmail.com

\begin{abstract}
ABSTRAK
Produk impor saat ini hampir menguasai sebesar 50\% pasar kosmetik Indonesia dipimpin oleh Korea Selatan. Selain memiliki populasi yang besar, Indonesia merupakan salah satu kantong fanbase Korean Wave terbesar di dunia. Survei yang dilakukan oleh ZAP Clinic menunjukkan bahwa Laneige menduduki posisi tertinggi dalam merek asal Korea Selatan yang paling sering digunakan oleh perempuan Indonesia. Salah satu produk Laneige dengan penjualan terbaik adalah Laneige Water Sleeping Mask. Produk ini pernah mencatat rekor terjual sebanyak 16 juta produk dan terjual setiap 12 detik. Laneige Water Sleeping Mask juga merupakan produk Laneige yang paling banyak diulas di Female Daily sebanyak 6.228 ulasan. Ulasan-ulasan di situs Female Daily dapat digunakan sebagai evaluasi dari suatu produk. Data tersebut berjumlah besar dan dapat diambil dengan metode web scraping melalui aplikasi tertentu. Penelitian ini menggunakan metode text mining untuk mengetahui sentimen dan topik serta kata apa saja yang sering dibicarakan terkait produk Laneige Water Sleeping Mask di Female Daily. Text mining yang digunakan adalah sentiment analysis dan topic modeling. Dataset yang digunakan adalah sebanyak 4.961 ulasan dengan proporsi $70 \%$ sebagai data latih dan $30 \%$ sebagai data uji. Hasil penelitian menggambarkan ulasan yang didominasi oleh sentimen positif serta topik dan kata-kata yang mengungkapkan kepuasan konsumen terhadap produk Laneige Water Sleeping Mask. Hasil ini dapat digunakan perusahaan sebagai informasi untuk dapat terus meningkatkan kualitasnya dikemudian hari.
\end{abstract}

\section{PENDAHULUAN}

Pasar kosmetik Indonesia mengalami pertumbuhan dari tahun ke tahun. Sebanyak 18,875 produk dari berbagai merek kosmetik telah beredar di seluruh Indonesia [1]. Saat ini telah ramai kegiatan jual beli online melalui e-commerce. Menurut Survei Asosiasi Penyelenggara Jasa Internet Indonesia (APJII), dari 7.000 sampel penduduk yang tersebar rata di seluruh wilayah Indonesia, produk fashion dan kecantikan merupakan jenis produk yang paling sering dibeli saat belanja online [2]. Produk kosmetik dari berbagai merek terus bermunculan setiap harinya, baik lokal maupun global. Terdapat kurang lebih 45 negara asal industri kosmetik dan kecantikan yang mengekspor produk-produknya ke Indonesia. Produk impor saat ini hampir menguasai sebesar 50\% pasar kosmetik Indonesia dipimpin oleh Korea Selatan sebesar 22,31\% [3].

Hasil survei dari ZAP Clinic pada tahun 2018 dan 2019 secara konsisten menungkapkan bahwa perempuan Indonesia paling suka produk kosmetik asal Korea Selatan 
[4]. Korea Selatan kini mampu muncul sebagai pemeran utama di industri kosmetik dan obatobatan herbal. Penetrasi industri kosmetik kini semakin dipermudah dengan budaya Korea Selatan berkembang dan meluas ke berbagai penjuru dunia dalam dua dekade terakhir [5]. Selain memiliki populasi yang besar, Indonesia merupakan salah satu kantong fanbase Korean Wave terbesar di dunia. Budaya Korea Selatan yang menyebar di seluruh dunia diawali dengan drama korea dan saat ini mencakup berbagai budaya seperti musik pop korea (K-pop), film, makanan, smartphone, fashion, kosmetik, dan lifestyle [6].

Menurut Asisten Manajer Riset Pasar Korea Trade-Investment Promotion Agency (KOTRA), terdapat kurang lebih 60 perusahaan kosmetik Korea Selatan tiap bulannya yang menjadikan Indonesia sebagai target pasarnya. Saat ini terdapat 15 merek yang berhasil masuk dan sedang ditangani oleh KOTRA, Laneige merupakan merek yang paling terkenal dan laris di pasar Indonesia [7]. Salah satu produk Laneige dengan penjualan terbaik adalah Laneige Water Sleeping Mask. Sejak diluncurkan pada tahun 2002, produk ini mencatat rekor terjual sebanyak 16 juta produk dan terjual setiap 12 detik [8]. Produk ini juga berhasil memenangkan enam penghargaan di Female Daily Best of Beauty Award di beberapa kategori [9]. Selain itu Laneige juga menjadi juara pertama dalam Cosmo Reader's Choice Award 2020 dalam kategori Night Treatment dan juara ketiga dalam Glowpick Beauty Award 2020 kategori Sleeping Mask dengan produk andalannya Laneige Water Sleeping Mask.

Laneige Water Sleeping Mask merupakan produk Laneige yang paling banyak diulas di Female Daily. Female Daily merupakan platform kecantikan berbasis situs web yang memberikan informasi seputar perempuan, terutama tentang kecantikan. Termasuk didalamnya adalah ulasan produk kecantikan, tips dan trik, opini pakar dan konsumen, tutorial kecantikan, diskusi, dll [10]. Dengan ulasan dari 6.228 pengguna, Laneige Water Sleeping Mask mendapatkan rating sebesar 4,2/5 dan 84\% merekomendasikannya kepada pembaca.

Seiring perkembangan teknologi, konsumen menjadi lebih aktif dalam mengakses informasi. Masyarakat menjadi semakin teliti dalam menentukan suatu produk yang akan dibeli terlebih keberadaan internet juga semakin memudahkan pengguna untuk mendapatkan informasi yang dibutuhkan. Ulasan-ulasan di situs Female Daily dapat digunakan sebagai evaluasi dari suatu produk. Perusahaan membutuhkan ulasan online untuk menyelidiki sikap dan persepsi konsumen terhadap produk mereka. Ulasan online juga merupakan jenis promosi yang berdampak besar pada pengambilan keputusan konsumen [11].

Data yang ada dalam ulasan online berjumlah besar dan akan memakan waktu yang lama apabila dilakukan dengan cara tradisional. Maka dari itu, data dapat diambil dengan metode web scraping melalui aplikasi tertentu. Dengan memanfaatkan perkembangan teknologi saat ini, big data dapat menjadi solusi untuk menghemat waktu yang dapat dilakukan untuk mengumpulkan dan menganalisis data dalam jumlah besar [12]. Dalam penelitian ini, ulasan-ulasan yang ada dalam situs Female Daily akan dianalisis menggunakan metode text mining. Text mining yang digunakan adalah sentiment analysis dan topic modeling untuk mengetahui sentimen dan topik apa saja yang sering muncul sehingga dapat memudahkan dalam mengetahui persepsi konsumen terhadap produk Laneige Water Sleeping Mask dari pengalaman setiap orang yang telah menggunakannya.

\section{Pemasaran}

Pemasaran adalah suatu sistem total dari kegiatan bisnis untuk merencanakan dan menentukan harga, mempromosikan dan mendistribusikan barang dan jasa yang dapat memuaskan keinginan konsumen saat ini maupun konsumen potensial. Pemasaran dilakukan dengan cara yang menguntungkan organisasi dan para pemegang saham untuk menciptakan, mengkomunikasikan, dan memberikan nilai kepada pelanggan [13].

\section{Pemasaran Digital}

Pemasaran digital merupakan segala hal mengenai penerapan internet dan teknologi digital terkait dalam hubungannya dengan komunikasi tradisional untuk mencapai tujuan 
pemasaran. Pemasaran digital mencakup mengelola berbagi bentuk kehadiran perusahaan online, seperti perusahaan situs web dan sosial media [14].

\section{Persepsi Konsumen}

Persepsi konsumen merupakan suatu proses yang membuat seseorang memilih, mengorganisasikan, dan menginterpretasikan rangsangan yang diterima menjadi sesuatu yang bermakna. Persepsi dapat bernilai positif maupun negatif. Jika seorang konsumen memiliki kesan positif terhadap sebuah produk, maka hal tersebut akan menghasilkan persepsi positif, begitu pula sebaliknya. Persepsi seseorang sangat dipengaruhi oleh pikiran dan lingkungan sekitar. Penilaian konsumen terhadap suatu produk didasarkan pada persepsi konsumen terhadap produk tersebut [15].

\section{Big Data}

Big data adalah kumpulan data dengan jumlah yang besar dan membutuhkan alat untuk mengambil dan menganalisisnya. Informasi dan data adalah hal yang sangat penting dan menjadi salah satu poin keberhasilan suatu organisasi. Big data memiliki 3 elemen kunci utama yang membedakan big data dari data biasa, volume (berapa banyak data), velocity (seberapa cepat data diolah) dan variety (beragam jenis data) [12].

\section{Text Mining}

Text mining merupakan proses menyaring wawasan baru atau memperkuat persepsi yang ada berdasarkan semua informasi yang relevan [16]. Text mining didasarkan pada teks, berkaitan dengan pencarian informasi relevan dari teks, dan mencari hubungan yang menarik atara entitas atau istilah yang diekstraksi [17]. Text mining mengacu pada proses penggalian informasi berkualitas tinggi dari sejumlah besar teks yang tidak terstruktur menggunakan metode dan teknik komputasi dengan tujuan untuk menemukan pola tersembunyi dari suatu sumber tertentu. Data tidak terstruktur dapat berupa artikel, buku, dan media sosial [18].

\section{Sentiment Analysis}

Analisis sentimen, juga disebut opinion mining, adalah bidang studi yang menganalisis pendapat, sentimen, penilaian, sikap, dan emosi orang-orang terhadap suatu entitas dan atribut mereka yang diungkapkan dalam teks tertulis. Entitas tersebut dapat berupa produk, layanan, organisasi, individu, peristiwa, masalah, atau topik. Kalimat yang mengekspresikan opini atau sentimen biasanya merupakan kalimat subjektif. Namun, kalimat objektif dapat menyiratkan sentimen positif atau negatif dari penulisanya juga, karena mereka dapat menggambarkan fakta yang diinginkan atau tidak diinginkan [19].

\section{Topic Modeling}

Topic modeling atau pemodelan topik adalah salah satu teknik paling kuat dalam text mining untuk penambangan data, penemuan data laten, dan menemukan hubungan antara data dan dokumen teks. Tujuan topic modeling yaitu menentukan topik secara otomatis dari sekumpulan dokumen. Dalam topic modeling, topik adalah daftar kata yang muncul dalam sebuah metode. Teks yang digunakan dapat berupa email, buku, blog, artikel, dan semua jenis teks lain yang tidak terstruktur [20].

Latent-Dirichlet Allocation (LDA) merupakan jenis algoritma yang paling populer, paling umum digunakan, dan dinilai efektif sebagai pendekatan dalam proses topic modeling. LDA dapat menemukan struktur topik tersembunyi dengan cara menemukan campuran kata yang terkait dengan topik lain. Setiap dokumen memiliki beberapa topik. Jumlah topik yang akan dihasilkan dapat ditentukan sebelum proses dilakukan. Topik yang ditemukan dengan LDA memiliki tingkat konsistensi dan keefektifan yang tinggi [21].

\section{METODE}

Penelitian ini menggunakan sumber data sekunder yaitu seluruh ulasan produk Laneige Water Sleeping Mask di situs Female Daily pada rentang waktu 1 Januari 2018 - 31 Desember 2020. Data yang diperoleh sebanyak 4.983 ulasan dengan menggunakan teknik web scraping dengan aplikasi Parsehub. Web scraping adalah teknik mengambil atau mengekstrak sebuah data dari suatu website secara spesifik. Parsehub merupakan aplikasi web scraper yang 
dapat digunakan untuk mengambil data keseluruhan dari sebuah situs. Terdapat empat informasi yang didapatkan dari Female Daily yaitu username, rentang umur, jenis kulit, dan ulasan.

Jumlah data yang digunakan berubah menjadi 4.961 ulasan setelah melalui preprocessing data. Teknik analisis data yang dilakukan dalam penelitian ini adalah sebagai berikut:

1. Pengumpulan Data: data yang digunakan dalam penelitian ini merupakan ulasan produk Laneige Water Sleeping Mask di Female Daily yang diperoleh dengan bantuan aplikasi Parsehub.

2. Preprocessing Data: pada tahap ini data yang tidak relevan, bernilai kosong, dan/atau inkonsistensi akan dihilangkan dengan bantuan aplikasi Rapid Miner karena akan mempengaruhi hasil. Tahapan preprocessing adalah sebagai berikut:

a. Case Folding: proses penyeragaman bentuk huruf menjadi huruf kecil dan penghilangan tanda baca yang tidak diperlukan.

b. Tokenizing: proses pemisahan teks menjadi potongan kata yang independen.

c. Filtering: proses pengurangan kata yang tidak digunakan sesuai dengan corpus (stopwords).

d. Stemming: proses mentransformasi kata ke dalam bentuk dasarnya.

3. Sentiment Analysis: analisis sentimen dilakukan dengan pendekatan Support Vector Machine (SVM) dengan aplikasi Rapid Miner.

4. Topic Modeling: pemodelan topik dilakukan dengan pendekatan Latent Dirichlet Allocation (LDA) untuk menemukan topik-topik yang sering dibicarakan konsumen dengan menggunakan aplikasi R Studio.

\section{HASIL DAN PEMBAHASAN}

Data yang telah melalui preprocessing dibagi menjadi data latih dan data uji dengan perbandingan 70:30. Data latih berisikan sekumpulan teks yang telah diklasifikasikan dengan memberikan label positif, negatif, dan netral secara manual. Data ulasan dengan persepsi positif atau mengandung kata-kata positif akan diberi label positif, data ulasan dengan persepsi negatif atau mengandung kata-kata negatif akan diberi label negatif, sedangkan data ulasan yang mengandung persepsi positif dan negatif, dianggap berada pada posisi netral. Proses ini dilakukan dengan machine learning manusia yang selanjunya akan dievaluasi oleh sistem.

Tabel 1. Contoh Klasifikasi Sentimen

\begin{tabular}{|l|c|}
\hline \multicolumn{1}{|c|}{ Teks } & Sentimen \\
\hline $\begin{array}{l}\text { secinta itu dengan tekstur dan hasil nya, bikin wajah lebih } \\
\text { lembab dan kulit lebih sehat. }\end{array}$ & Positif \\
\hline $\begin{array}{l}\text { di aku ga ngefek sm sekali setelah pake ini muka nya gatel } \\
\text { dan beruntusan... sedih banget }\end{array}$ & Negatif \\
\hline $\begin{array}{l}\text { bantu banget buat ngelembapin paginya glowing kenyal. Tapi } \\
\text { pemakaian beberapa hari malah muncul jerawat }\end{array}$ & Netral \\
\hline
\end{tabular}

Data latih digunakan untuk melatih sistem dengan model yang diberikan dan selanjutnya akan diterapkan pada data uji untuk dievaluasi, sehingga dari data uji dapat diketahui performa sistem yang telah dilatih sebelumnya dengan data latih. Dalam proses olah data latih dan data uji, sistem dapat memproses dan mengevaluasi hasil klasifikasi dengan baik. Hal ini dapat diketahui karena data memiliki tingkat akurasi yang tergolong tinggi yaitu 81,63\%. Akurasi adalah persentase ketepatan klasifikasi data setelah dilakukan pengujian. Akurasi merupakan rasio data yang diprediksi benar dengan total data[22]. Selain itu tingkat presisi dan recall didapatkan sebesar 52,26\% dan 70,84\%. 
Tabel 1. Hasil Evaluasi Performansi

\begin{tabular}{|c|c|c|}
\hline Akurasi & Presisi & Recall \\
\hline $81,63 \%$ & $52,26 \%$ & $70,84 \%$ \\
\hline
\end{tabular}

\section{Sentiment Analysis}

Dari total 4.961 data yang telah diolah, sentimen positif mendominasi dataset yang digunakan sebesar $76 \%$. Sedangkan sisanya, $15 \%$ berlabel negatif, dan 9\% berlabel netral. Persepsi konsumen terhadap produk Laneige Water Sleeping Mask dapat dikatakan sangat baik karena persentase sentimen positif sangat jauh dibandingkan dengan persentase sentimen negatif dan netral.

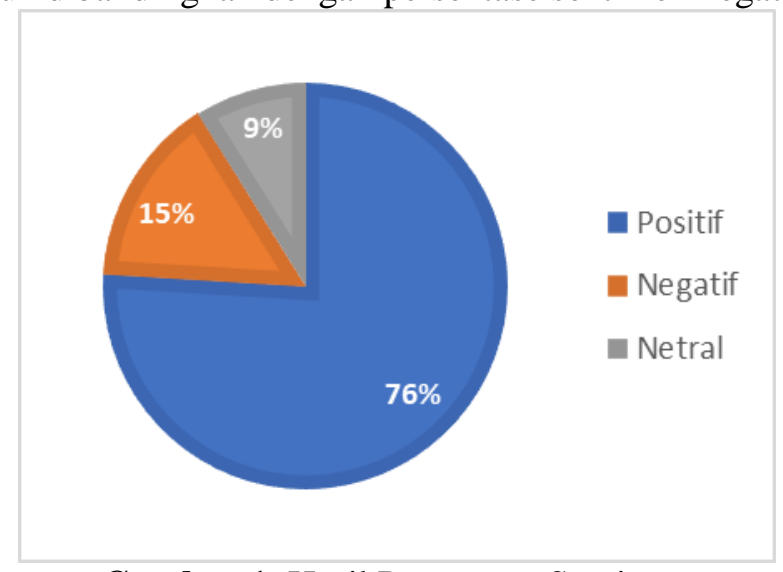

Gambar 1. Hasil Persentase Sentimen

\section{Topic Modeling}

LDA-Based Topic Modeling merupakan pendekatan pemodelan topik yang digunakan untuk mengetahui topik yang terbentuk pada dokumen dengan tingkat konsistensi dan keefektifan yang tinggi. Jumlah kelompok topik yang optimal adalah antara empat dan sembilan dihitung berdasarkan teknik teknik maksimisasi dan minimisasi. Namun, lima adalah jumlah topik yang sering digunakan demi kesederhanaan diskusi [23].

Gambar 4.2 merupakan topik-topik yang sering dibicarakan pengguna terhadap produk Laneige Water Sleeping Mask secara keseluruhan yang divisualisasikan dalam lima topik. Angka pada sumbu x merupakan beta yang menunjukkan seberapa sering kata tersebut muncul pada suatu topik. Semakin tinggi nilai beta, maka semakin tinggi pula frekuensi kemunculan kata-kata tersebut dalam suatu kelompok topik. Topik keseluruhan yang dibicarakan tersebut adalah sebagai berikut:

1. Topik pertama berisikan kata yang mengandung kata-kata positif terhadap produk.

2. Topik kedua membahas tentang konsumen yang mulai puas dengan produk Laneige Water Sleeping Mask dan akan melakukan pembelian ulang.

3. Beberapa konsumen merasa tidak cocok dengan produk Laneige Water Sleeping Mask karena menimbulkan efek lain yang tidak diharapkan seperti jerawat dan minyak berlebih.

4. Produk ini memberikan efek melembabkan bagi kulit wajah, namun memiliki harga yang kurang terjangkau. Hal ini tercermin dari pembahasan di topik keempat yaitu harga mahal.

5. Pada topik terakhir membahas tekstur produk berupa gel yang mudah menyerap dan aroma yang wangi serta efek kenyal dan bercahaya pada kulit wajah. 

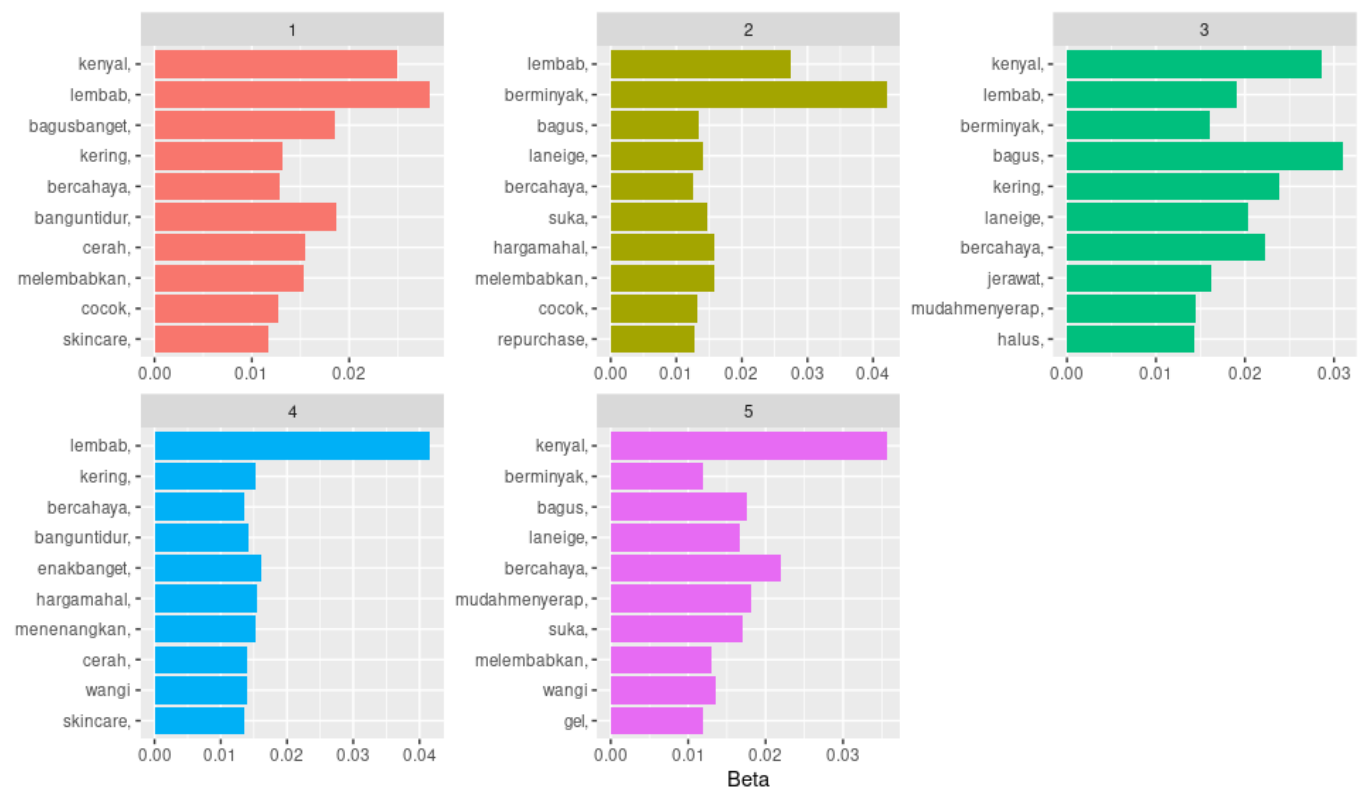

Gambar 2. Hasil Topic Modeling Keseluruhan

\section{Topic Modeling Positif}

Lima topik positif yang sering dibicarakan pengguna terhadap produk Laneige Water Sleeping Mask divisualisasikan pada Gambar 3 :

1. Produk dapat memberikan efek bercahaya, lembab, kenyal, dan tekstur yang mudah menyerap terhadap kulit wajah sehingga konsumen menyukai produk Laneige Water Sleeping Mask.

2. Konsumen merasa puas karena produk dapat memberikan hasil yang sepadan ketika bangun tidur dengan harga yang ditawarkan.

3. Konsumen merasa nyaman karena mendapatkan efek lembab, kenyal, dan wangi yang menenangkan pada kulit wajah sehingga akan melakukan pembelian ulang terhadap produk.

4. Produk dapat membuat kulit wajah lebih bercahaya, lembab, dan cerah.

5. Produk banyak disukai oleh konsumen karena memberikan hasil yang memuaskan.
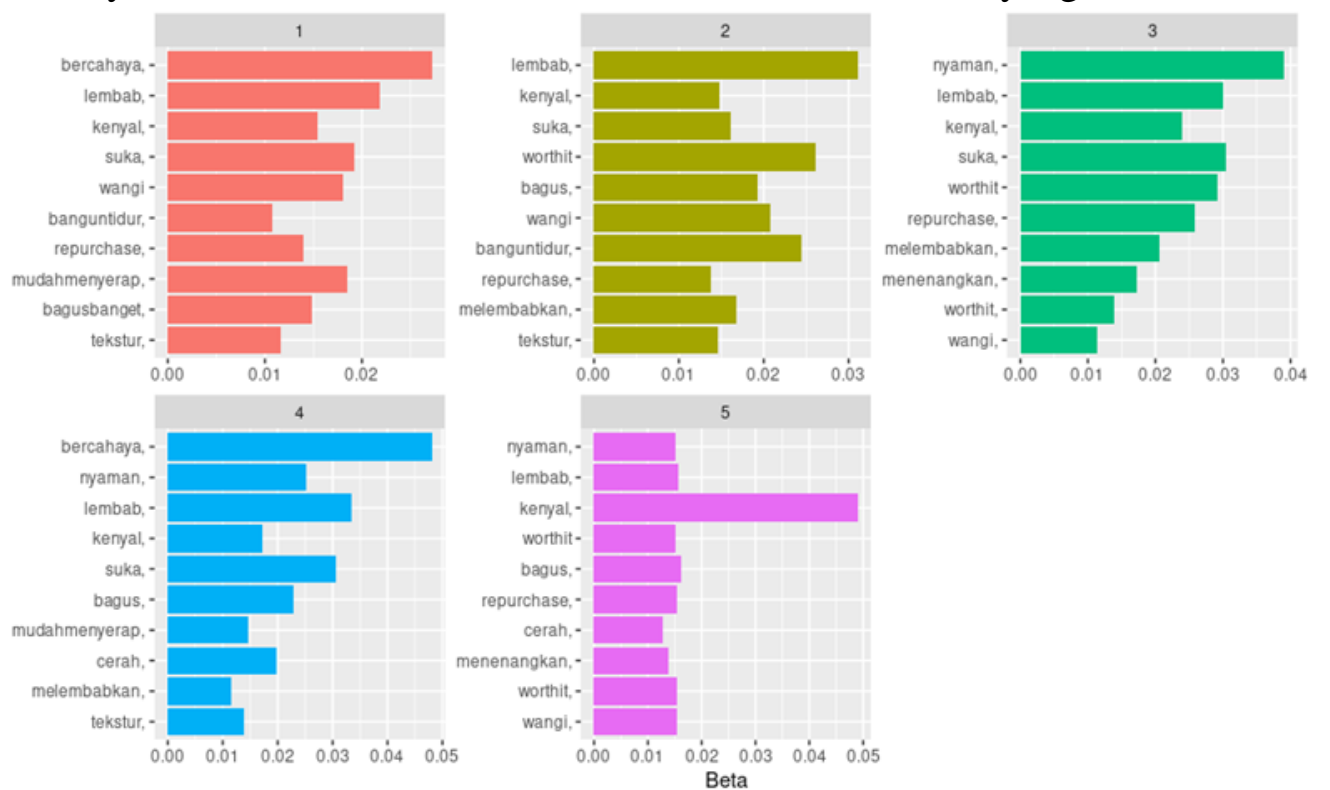

Gambar 3. Hasil Topic Modeling Positif 


\section{Topic Modeling Negatif}

Topik dengan sentimen negatif yang dibicarakan pengguna di situs Female Daily terhadap produk Laneige Water Sleeping Mask diantaranya adalah sebagai berikut:

1. Konsumen merasa tidak cocok dengan produk karena membuat kulit wajah menjadi kering, beruntusan, dan memiliki aroma yang mengganggu.

2. Konsumen merasa kecewa karena produk karena dapat memberikan efek yang mengganggu seperti kulit wajah beruntusan, kering, dan kusam.

3. Konsumen tidak cocok dan kecewa dengan produk karena membuat kulit wajah berjerawat, kusam, dan berminyak.

4. Konsumen kecewa dengan produk karena harga yang mahal, aroma yang menyengat, dan membuat kulit wajah berjerawat dan berminyak.

5. Konsumen tidak cocok dengan produk karena membuat kulit wajah berjerawat, beruntusan, kering, dan memiliki aroma yang mengganggu.
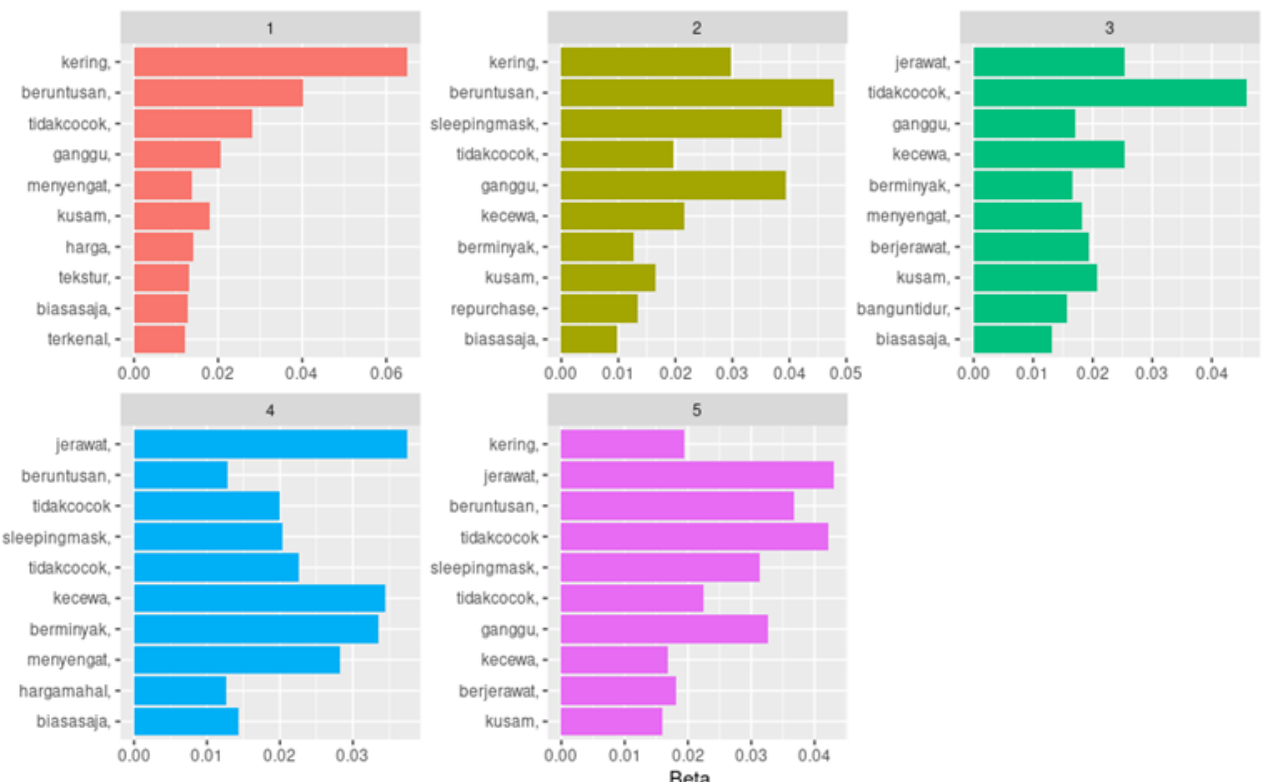

Gambar 4. Hasil Topic Modeling Negatif

\section{Topic Modeling Netral}

Topik dengan sentimen netral yang sering dibicarakan pengguna di situs Female Daily terhadap produk Laneige Water Sleeping Mask pada tanggal 1 Januari 2018 - 31 Desember 2020 adalah sebagai berikut:

1. Produk biasa saja, memberikan efek lembab, kenyal, dan bercahaya namun berminyak dan beruntusan.

2. Produk memiliki kualitas yang bagus, melembabkan, mengenyalkan, dan mencerahkan, namun dapat memunculkan jerawat dan meningkatkan kadar minyak pada kulit wajah.

3. Konsumen merasakan kelembaban pada kulit wajah yang cenderung biasa saja.

4. Produk dapat melembabkan kulit wajah, namun juga meningkatkan kadar minyak.

5. Konsumen menyukai produk karena dapat melembabkan, dan memiliki wangi yang menenangkan, namun harga yang ditawarkan relatif mahal. 

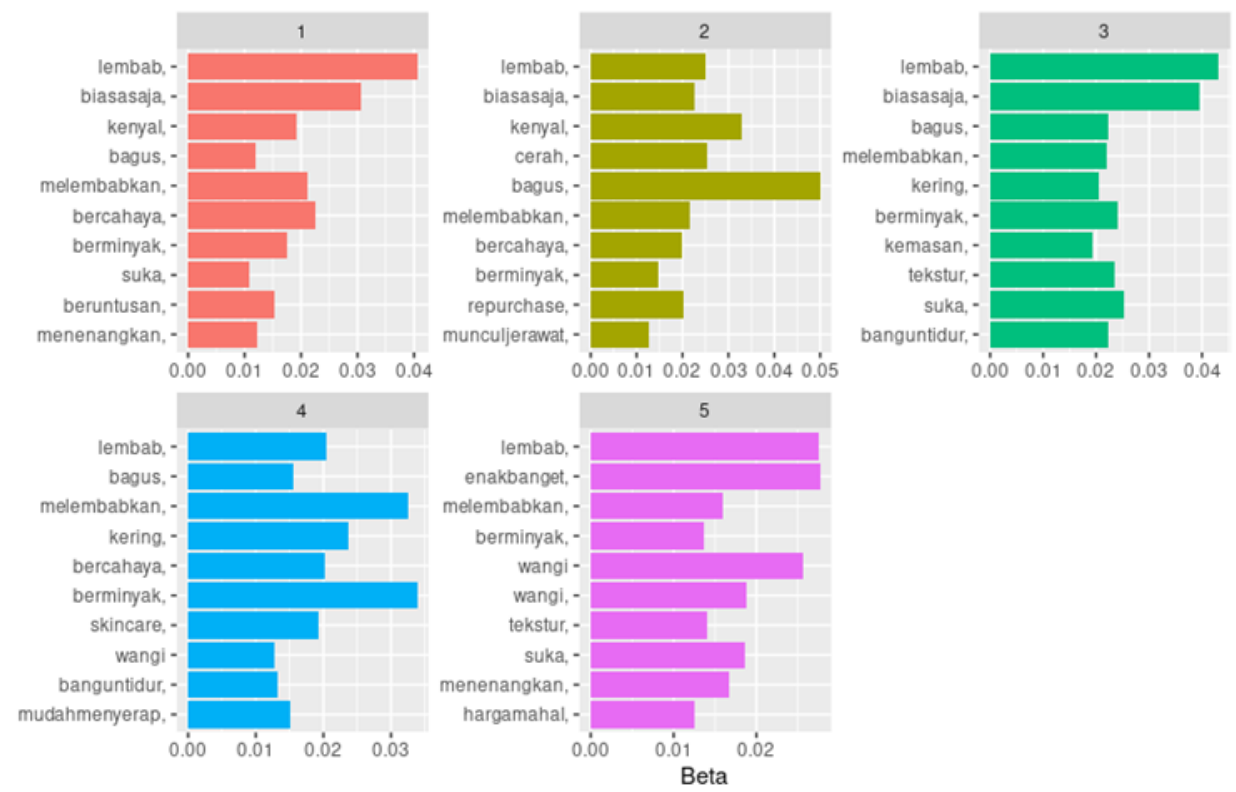

Gambar 5. Hasil Topic Modeling Netral

\section{SIMPULAN DAN SARAN}

Sentimen yang terbentuk dalam kolom ulasan produk Laneige Water Sleeping Mask di Female Daily adalah didominasi oleh sentimen positif dengan persentase sebesar $76 \%$. Hal ini menunjukkan bahwa sebagian besar konsumen merasa puas terhadap kualitas produk Laneige Water Sleeping Mask. Dengan demikian dapat dikatakan bahwa Lanige Water Sleeping Mask merupakan produk dengan kualitas yang baik untuk perawatan wajah.

Hasil dari topik keseluruhan didominasi oleh ungkapan kepuasan terhadap kualitas produk karena produk memberikan hasil yang baik terhadap kulit wajah meskipun ada beberapa yang merasakan hasil yang tidak diharapkan. Topik yang dibahas pada sentimen positif adalah ungkapan rasa suka terhadap produk Laneige Water Sleeping Mask karena membuat kulit wajah menjadi kenyal, lembab, dan bercahaya. Hal ini dapat menjadi wawasan perusahaan mengenai hal-hal yang menarik perhatian konsumen sehingga perusahaan dapat terus mempertahankan bahkan meningkatkan kualitas produk Laneige Water Sleeping Mask di kemudian hari. Topik yang dibahas pada sentimen negatif merupakan ungkapan kekecewaan konsumen terhadap produk dinilai tidak memberikan hasil seperti yang diharapkan konsumen. Konsumen merasa tidak cocok dengan produk ini karena membuat kulit wajah menjadi berminyak, berjerawat, dan beruntusan. Selain itu produk ini memiliki harga yang relatif mahal. Hal ini dapat menjadi fokus perusahaan dalam mengevaluasi dan memperbaiki kualitas produk sehingga dapat lebih baik lagi kedepannya. Topik yang dibahas pada sentimen netral adalah konsumen yang mengungkapkan rasa suka terhadap produk karena membuat kulit wajah menjadi lembab dan kenyal. Namun konsumen juga merasa bahwa produk ini membuat kulit wajah menjadi berminyak. Maka dari itu, perusahaan tetap perlu melakukan evaluasi terhadap produk sehingga dapat memperbaiki kesalahan-kesalahan sebelumnya.

Untuk penelitian selanjutnya, diharapkan dapat memperkaya data yang akan diolah dengan keberagaman sumber data sehingga dapat membentuk pola yang lebih baik lagi untuk diteliti. Selain itu, diharapkan pula dapat menggunakan objek produk atau merek yang berbeda atau beragam sehingga dapat membandingkan kualitas antar produk atau merek.

\section{DAFTAR PUSTAKA}

[1] BPOM RI, “Cek Produk BPOM - BPOM RI,” 2020. .

[2] APJII, "Laporan Survei Internet APJII 2019 - 2020," Asos. Penyelenggara Jasa Internet Indones., vol. 2020, pp. 1-146, 2020, [Online]. Available: 
https://apjii.or.id/survei.

[3] Kemenperin, "Kemenperin: Produk Impor Kuasai Pasar Kosmetik," 2019. https://kemenperin.go.id/artikel/11943/Produk-Impor-Kuasai-Pasar-Kosmetik (accessed Feb. 26, 2021).

[4] ZAP Clinic and MarkPlus, “ZAP Beauty Index 2020,” Zap Clin. Index, pp. 1-36, 2020, [Online]. Available: https://zapclinic.com/zapbeautyindex.

[5] R. Lukafiardi, "Fenomena Korean Wave di Indonesia - Environmental Geography Student Association," 2020. https://egsa.geo.ugm.ac.id/2020/09/30/fenomena-koreanwave-di-indonesia/ (accessed Feb. 26, 2021).

[6] Y. Kim, The Korean Wave: Korean Media Go Global - Google Buku. New York: Routledge, 2013.

[7] R. D. Putri, "Indonesia, Target Pasar Seksi K-Beauty di Asia," Tirto.id, 2017. https://tirto.id/indonesia-target-pasar-seksi-k-beauty-di-asia-cyRj (accessed Feb. 24, 2021).

[8] Laneige, "Kisah Laneige - $\quad$ Sejarah Merek," 2020. https://www.laneige.com/id/id/laneige-story/history/history.html.

[9] Female Daily, "Laneige Water Sleeping Mask - Review Female Daily," 2021. https://reviews.femaledaily.com/products/mask/sleeping-mask/laneige/water-sleepingmask?cat $=\&$ cat_id $=0 \& a g e \_r a n g e=\&$ skin_type $=\&$ skin_tone $=\&$ skin_undertone $=\&$ hair_t exture $=\&$ hair_type $=\&$ order $=$ newest $\&$ page $=1$ (accessed Feb. 27, 2021).

[10] Female Daily, “About Us,” 2021. https://femaledaily.com/about.

[11] K. S. Guen and K. Juyoung, "Analyzing the discriminative attributes of products using text.pdf," Inf. Process. Manag., 2018, doi: https://doi.org/10.1016/j.ipm.2018.06.003.

[12] M. Kubina, M. Varmus, and I. Kubinova, "Use of Big Data for Competitive Advantage of Company," Procedia Econ. Financ., vol. 26, no. 15, pp. 561-565, 2015, doi: 10.1016/s2212-5671(15)00955-7.

[13] Hery, Manajemen Pemasaran. Jakarta: PT Grasindo, 2019.

[14] D. Chaffey and F. Ellis-Chadwick, Digital Marketing: Strategy, Implementation, and Practice, Sixth Edit. Harlow: Pearson Education Limited, 2016.

[15] M. A. Firmansyah, PERILAKU KONSUMEN (Sikap dan Pemasaran). Yogyakarta: DEEPUBLISH, 2018.

[16] T. Kwalter, Text Mining in Practice with R. Chichester: John Wiley \& Son Ltd, 2017.

[17] B. Makhabel, P. Mishra, N. Danneman, and R. Heimann, $R$ : mining spatial, text, web, and social media data: create and customize data mioning algorithms: a course in three modules. Birmingham: Packt Publishing, 2017.

[18] S. Yang and H. Zhang, "Text Mining of Twitter Data Using a Latent Dirichlet Allocation Topic Model and Sentiment Analysis," Int. J. Comput. Inf. Eng., vol. Vol. 12 No, 2018.

[19] B. Liu, Sentiment analysis: Mining opinions, sentiments, and emotions. USA: Cambridge University Press, 2015.

[20] H. Jelodar et al., "Latent Dirichlet allocation (LDA) and topic modeling: models, applications, a survey," Multimedia Tools and Applications, vol. 78, no. 11. pp. 1516915211, 2019, doi: 10.1007/s11042-018-6894-4.

[21] C. Zou, "Analyzing research trends on drug safety using topic modeling," Expert Opin. Drug Saf., vol. 17, no. 6, pp. 629-636, 2018, doi: 10.1080/14740338.2018.1458838.

[22] J. Han and M. Kamber, Data Mining: Concepts and Techniques, Second Edi. San Fransisco: Morgan Kaufmann Publisher, 2006.

[23] R. A. Masrury, Fannisa, and A. Alamsyah, "Analyzing Tourism Mobile Applications Perceived Quality using Sentiment Analysis and Topic Modeling," 2019. 